Original article

\title{
Climat and malign skin tumors (research with geografic information system in Khabarovsk Krai)
}

\author{
A.Y. Marocho ${ }^{1}$, Alex S. Vavrinchuk ${ }^{1}$, N.E. Kosyh ${ }^{1}$, E.V. Pryanishnikov ${ }^{2}$ \\ ${ }^{1}$ Far East State Medical University, Khabarovsk, Russia \\ ${ }^{2}$ Far East Clinical Centre of Oncology, Khabarovsk, Russia
}

Received 19 December 2013, Accepted 25 December 2013

(C) 2013, Marocho A.Y., Vavrinchuk A.S., Kosyh N.E., Pryanishnikov E.V.

(C) 2013, Russian Open Medical Journal

\begin{abstract}
In this research the effect of 12 climate risk factors of skin cancer and skin melanoma were studied in a population of Khabarovsk Krai using climate geographic information system by the methods of correlation and regression analysis. It was found that the incidence of skin cancer strongly correlated with the levels of total annual absorbed shortwave radiation, the absolute minimum air temperature in January, the annual radiation balance and the monthly average air temperature in January. Regression analysis revealed a high degree of morbidity due to the complex of climatic factors, the most important of which are: the annual absorbed shortwave radiation, the absolute minimum air temperature in January, the annual radiation balance and the annual total solar radiation. At the same time, a high risk of skin melanoma associated with exposure to the population of the complex of climatic factors, among which the most significant, increase the risk of the disease are: average humidity and average monthly temperature in July, and the repeatability of a cloudy sky in July.
\end{abstract}

Keywords: geographic information system, skin melanoma, skin cancer

Cite as Marocho AY, Vavrinchuk AS, Kosyh NE, Pryanishnikov EV. Climat and malign skin tumors (research with geografic information system in Khabarovsk Krai). Russian Open Medical Journal 2014; 3: 0106.

Correspondence to Alex Vavrinchuk. E-mail: sandorkligan@gmail.com

\section{Introduction}

The study of prevalence of malignant neoplasms is frequently performed without taking into account the endemic specifics of particular territories and effect of complex of environmental factors on humans [1].

Due to its geographic location and variety of climatic characteristics of the territory Khabarovsk Krai is a convenient model to study the particularities of prevalence of malignant tumors on Far East. The northern regions in many characteristics are similar to adjacent Yakut Republic and Magadan Region, the southern ones are similar to Primorsky Krai, the coastal ones are similar to Sakhalin region and southern parts of Kamchatka, the western ones are similar to neighboring Jewish Autonomous Region and Amur Region [2]

Skin cancer and skin melanoma are characterized by expressed territorial geographic variance of distribution with large fluctuation of worldwide disease prevalence in men and women $[3,4]$. Presently the fact of effect of solar radiation o0n the risk of those tumors manifestation is well established [5-8]. But the role of other climatic factors in development of those neoplasms is not sufficiently studied [9].

Standard methodology approach does not allow to made a conclusion on degree of influence of the whole complex of environmental factors (temperature regimen, solar insolation, air humidity) on the risk of cancer and skin melanoma $[6,9]$. It is possible to evaluate its role using climatic geographic information system which allows us to select the complex of factors affecting the prevalence of neoplasms in population, as well as evaluate the role of those factors for development of malignant skin tumors [2].

Study objective: use the climatic geographical information system to determine climatic factors with the most influence on the risk of manifestation of skin cancer and skin melanoma in population.

\section{Material and Methods}

To create geographic information system we used the Khabarovsk Krai map characterizing the climatic regime on the following parameters (climatic factors):

i) Repetitiveness of murky sky (8-10 points) from total cloud cover in January (\% of days), named as $\mathrm{X} 1$;

ii) Number of murky days from total cloud cover per year (\%), named as $\mathrm{X} 2$;

iii) Repetitiveness of murky sky (8-10 points) from total cloud cover in July (\% of days), named as X3

iv) Average monthly air temperature in July $\left({ }^{\circ} \mathrm{C}\right)$, named as $\mathrm{X} 4$;

v) Annual rainfall ( $\mathrm{mm})$, named as $\mathrm{X5}$;

vi) Absolute minimum air temperature in January $\left({ }^{\circ} \mathrm{C}\right)$, named as X6;

vii) Average monthly air temperature in January $\left({ }^{\circ} \mathrm{C}\right)$, named as X7;

viii) Annual radiation balance $\left(\mathrm{MJ} / \mathrm{m}^{2}\right)$, named as $\mathrm{X} 8$;

ix) Annual total solar radiation $\left(\mathrm{MJ} / \mathrm{m}^{2}\right)$, named as $\mathrm{X}$; 
x) Annual absorbed short-wave radiation $\left(\mathrm{MJ} / \mathrm{m}^{2}\right)$, named as X10;

xi) Average annual evaporation (mm), named as X11;

xii) Average monthly relative air humidity in July (\%), named as $\mathrm{X} 12$.

By using the cluster analysis the Krai territory was separated into 10 clusters with similar climatic parameters (Figure 1). It is worth to note that borders of clusters do not match the borders of administrative district of Krai. A number of districts (Nikolaevsk, Sovetskaya Gavan) contained the clusters of three types. At the same time the cluster No.4 contained only one settlement which leads to exclusion of the cluster from the studies. For each of 9 clusters we defined the average values for each of 12 abovementioned climatic parameters, population number (human-years) and total prevalence of skin cancer in the period from 2000 till 2009 and skin melanoma in the period from 1990 till 2007 (based on the data of Krai cancer register).

The disease prevalence was calculated as standardized parameter using "world standard" of population (by 100,000 persons). We defined the values of relative risk of skin cancer and skin melanoma in population of different clusters, as well as $\mathrm{Cl}$ $95 \%$ values for said parameter. The standard (1.0) was the disease prevalence in all clusters.

To study the effect if climatic factors (designated as X1-12) we calculated the coefficients of pair correlation between single factors and degree of prevalence of skin cancer and skin melanoma in population of different clusters. Also in order to evaluate the connection between studied phenomena we used the analysis of multiple linear regressions with regression model generation [2]. The equation was considered valid with approximation coefficient value $R^{2}>0.3$. Statistically significant difference was $p<0.05$.

\section{Results}

Formed clusters differed from each other in its geographical positions and characteristics of climatic parameters. The clusters No. 1, 2 and 3, located on the north of the Krai, were characterized by low minimal and average monthly air temperatures in January and average monthly temperatures in July, relatively small annual rainfall, low values of annual evaporation and monthly air humidity in July, as well as low levels of annual total solar and absorbed short-wave radiation, as well as annual radiation balance. At the same time we noted a large number of murky days in the year, as well as relatively high repetitiveness of murky sky in January.

Clusters No. 8, 9 and 10 were located in southern; most populated and developed territories of Khabarovsk Krai. They are characterized by relatively mild climate in January combined with high average monthly air temperatures and values of average monthly radiation in July; high levels of annual total solar and absorbed short-wave radiation, as well as annual radiation balance; large annual rainfall and evaporation values. Compared to other clusters the number of murky days per year was small.

Clusters No. 5, 6 and 7 were located mostly on the territory of the central regions of Krai and their climatic characteristics were in the intermediate position between "Northern" and "Southern" cluster groups.

The increase of the relative risk of skin cancer and skin melanoma was noted in the population of clusters located in the south of the Krai. The highest relative risk of skin cancer manifestation was displayed in the population of settlements located in cluster No.6 including the city of Komsomolsk-on-Amur - 1.18 (1.11-1.25). High statistically significant parameters of relative risk of skin melanoma manifestation were observed in the settlements located in cluster No.8 where the Khabarovsk city was located- 1.15 (1.04-1.26) (Tables 1 and 2).

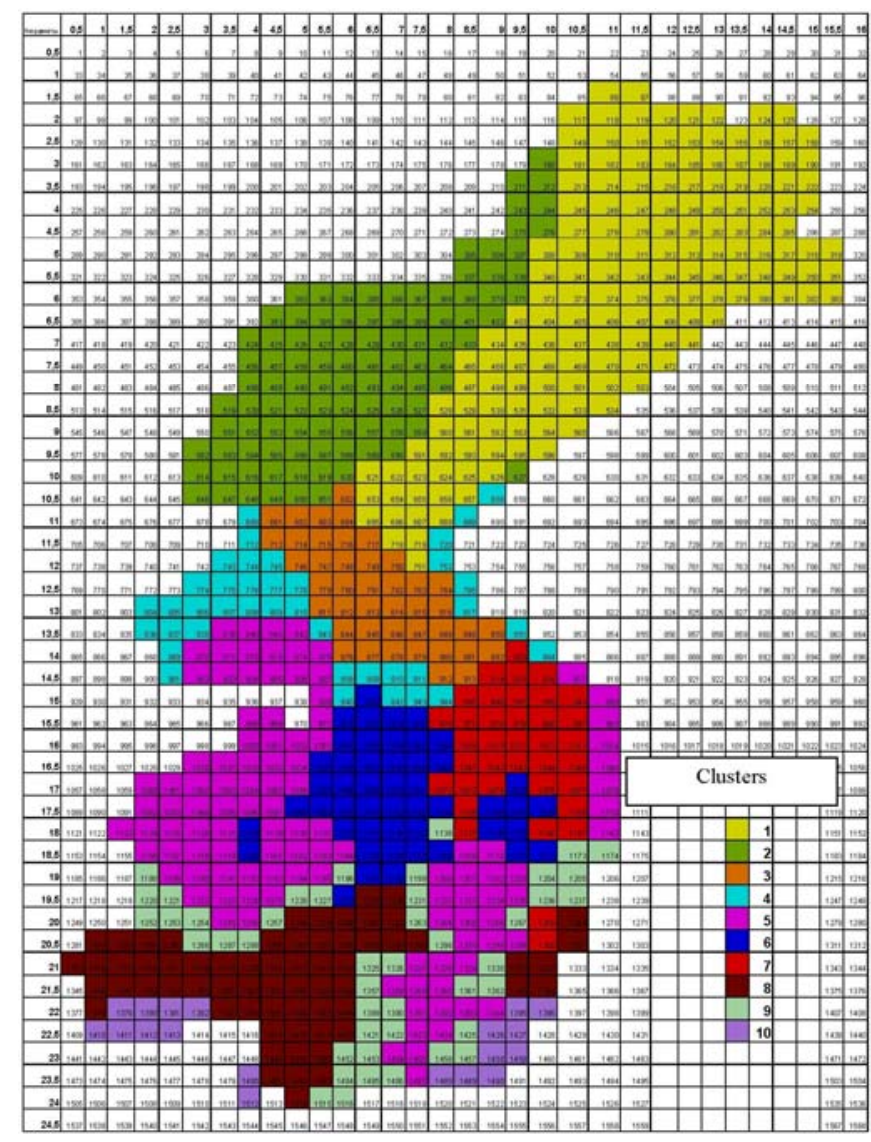

Figure 1. Climatic clusters of Khabarovsk Krai

Table 1. Population, disease prevalence and relative risk of skin cancer in climatic clusters of Khabarovsk Krai (2000-2009 years)

\begin{tabular}{lrrrrr}
\hline $\begin{array}{l}\text { Cluster } \\
\text { No }\end{array}$ & Population & $\begin{array}{c}\text { Number } \\
\text { of cases }\end{array}$ & $\begin{array}{c}\text { Disease } \\
\text { prevalence } \\
\text { by } \\
\text { 100,000 } \\
\text { persons }\end{array}$ & $\begin{array}{c}\text { Relative } \\
\text { risk }\end{array}$ & Cl,95\% \\
\hline 1 & 134,270 & 13 & 9.7 & $0.28^{*}$ & $0.16-0.49$ \\
2 & 18,626 & 1 & 5.4 & 0.16 & $0.02-1.11$ \\
3 & 30,708 & 2 & 6.5 & $0.19^{*}$ & $0.05-0.76$ \\
5 & 826,170 & 237 & 28.7 & $0.83^{*}$ & $0.73-0.95$ \\
6 & $3,321,830$ & 1343 & 40.4 & $1.18^{*}$ & $1.11-1.25$ \\
7 & 215,353 & 57 & 26.5 & 0.77 & $0.59-1.00$ \\
8 & $9,007,260$ & 3057 & 33.9 & 0.99 & $0.94-1.03$ \\
9 & 222,556 & 40 & 18.0 & $0.52^{*}$ & $0.38-0.71$ \\
10 & 289,750 & 87 & 30.0 & 0.87 & $0.71-1.08$ \\
\hline Total & $14,066,523$ & 4837 & 34.4 & 1.0 &...- \\
\hline
\end{tabular}


Table 2. Population, disease prevalence and relative risk of skin melanoma in climatic clusters of Khabarovsk Krai in 1990-2007 years

\begin{tabular}{lrcccc}
\hline $\begin{array}{l}\text { Cluster } \\
\text { No }\end{array}$ & Population & $\begin{array}{c}\text { Number } \\
\text { of cases }\end{array}$ & $\begin{array}{c}\text { Disease } \\
\text { prevalence } \\
\text { by 100,000 } \\
\text { persons }\end{array}$ & $\begin{array}{c}\text { Relative } \\
\text { risk }\end{array}$ & Cl, 95\% \\
\hline 1 & 241,694 & 6 & 2.5 & 0.61 & $0.27-1.37$ \\
2 & 33,527 & - & - & - & - \\
3 & 55,274 & 1 & 1.8 & 0.45 & $0.06-3.18$ \\
5 & $1,487,106$ & 34 & 2.3 & $0.56^{*}$ & $0.40-0.79$ \\
6 & $5,979,294$ & 188 & 3.1 & $0.79^{*}$ & $0.66-0.91$ \\
7 & 387,634 & 12 & 3.1 & 0.76 & $0.43-1.35$ \\
8 & $16,213,068$ & 752 & 4.6 & $1.15^{*}$ & $1.04-1.26$ \\
9 & 400,601 & 9 & 2.2 & 0.55 & $0.29-1.07$ \\
10 & 521,554 & 23 & 4.4 & 1.09 & $0.72-1.65$ \\
\hline Total & $25,319,752$ & 1025 & 4.0 & 1.0 & - \\
\hline
\end{tabular}

Table 3. Coefficients of pair correlation ( $r$ ) between climatic factors and prevalence of skin cancer in Khabarovsk Krai (2000-2009 years)

\begin{tabular}{lc}
\hline \multicolumn{1}{c}{ Climatic factors } & $r$ \\
\hline Annual absorbed short-wave radiation & 0.797 \\
Absolute minimum air temperature in January & 0.778 \\
Annual radiation balance & 0.766 \\
Average monthly air temperature in January & 0.720 \\
Average monthly relative air humidity in July & 0.710 \\
Annual rainfall & 0.706 \\
Annual total solar radiation & 0.701 \\
Average annual evaporation & 0.676 \\
Average monthly air temperature in July & 0.603 \\
Repetitiveness of murky sky (8-10 points) from total cloud & 0.106 \\
cover in July & \\
Number of murky days from total cloud cover per year & -0.316 \\
Repetitiveness of murky sky (8-10 points) from total cloud & -0.405 \\
cover in January & \\
\hline
\end{tabular}

Table 4. Coefficients of pair correlation ( $r$ ) between climatic factors and prevalence of skin melanoma in Khabarovsk Krai (1990-2007 years) Climatic factors

Average monthly relative air humidity in July

$r$

0.809

Absolute minimum air temperature in January

0.799

0.770

0.679

0.666

Average annual evaporation

Average monthly air temperature in July

0.617

0.606

0.602

Annual absorbed short-wave radiation

Repetitiveness of murky sky (8-10 points) from total cloud

0.556

cover in July

Annual radiation balance

Number of murky days from total cloud cover per year

0.538

$-0.522$

Repetitiveness of murky sky (8-10 points) from total cloud

cover in January

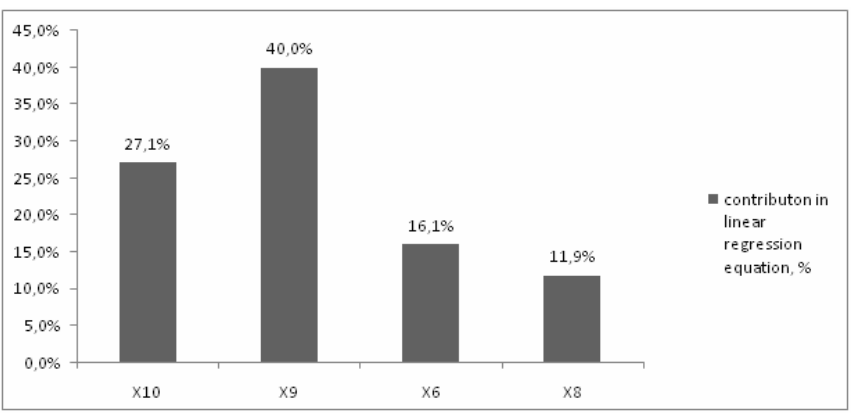

Figure 2. Contribution of climatic factors in the multiple linear regression equation for skin cancer
The lowest relative risk of skin cancer manifestation was observed in clusters No.1 - 0.28 (0.16-0.49) and No.3 - 0.19 (0.05$0.76)$, while the parameters of the relative risk of skin melanoma manifestation were not statistically significant due to the rarity of the pathology on those territories.

In the study period the majority of Krai population resided in major centers - city of Khabarovsk (38.5\%) and Komsomolsk $(17.6 \%)$. When excluding from the study the cases from those major industrial centers statistically significant low values of relative risk of skin cancer manifestation remained in clusters No. $1-0.36$ (0.21-0.62), No.3 - 0.24 (0.06-0.97) and No.9-0.67 (0.490.92 ), while the relative risk of skin cancer manifestation in cluster No.6 became statistically insignificant - 0.93 (0.78-1.12). Low values of relative risk of skin cancer manifestation remained in cluster No. $6-0.41$ (0.22-0.76).

Correlation analysis between climatic parameters and skin cancer prevalence in Khabarovsk Krai showed that the factors with the highest correlation coefficient involved: annual absorbed short-wave radiation $(0.797)$, absolute minimum air temperature in January (0.770), annual radiation balance $(0.766)$ and average monthly air temperature in January (0.720) (Table 3).

The regression analysis performed allowed us to get the multiple linear regression equation as follows:

$$
Y=0.0813 * x 10-0.1057 * x 9+3.2932 * x 6+0.0698 * x 8,
$$

where $Y$ - prevalence of skin cancer in Khabarovsk Krai,

$\mathrm{X} 10$ - annual absorbed short-wave radiation,

X9 - annual total solar radiation,

X6 - absolute minimum air temperature in January

X8 - annual radiation balance.

Approximation coefficient $\mathrm{R}^{2}$ was 0.950 , signifying the validity of the equation $(p=0.026)$. At the same time the highest contribution to $Y$ value was made by components $X 9$ (annual total solar radiation) $-40.0 \%$ and $\mathrm{X} 10$ (annual absorbed short-wave radiation) $-27.1 \%$, with the latter having negative value in the resulting equation. The contribution of components $X 6$ (absolute minimum air temperature in January) and $\mathrm{X} 8$ (annual radiation balance) were lower $-16.1 \%$ and $11.9 \%$ respectively (Figure 2 ).

Coefficients of pair correlation of those factors with skin cancer prevalence were high (Table 4). But the strongest direct connection was with annual absorbed shortwave radiation ( $r=0.797)$

In order to study the degree of mutual connection we calculated the coefficients of pair correlation between separate climatic factors (Table 5). It is worth to note that the strongest mutual connection was shown by parameters of annual radiation balance and annual total solar radiation ( $r=0.957)$, proving the importance of solar radiation contribution to the disease development. Values of annual absorbed short-wave radiation are the most closely connected to the annual radiation balance $(r=0.970)$, annual total solar radiation $(r=0.967)$, annual rainfall $(r=0.894)$, absolute minimum air temperature in January $(r=0.832)$.

Use of correlation analysis to detect the connection between climatic parameters and prevalence of melanoma showed that the most expressed direct connection degree was noted for such factors as average monthly air humidity in July ( $r=0.809)$, average monthly and minimum air temperature in January $(r=0.799$ and $r=0.770$ respectively), annual rainfall ( $r=0.679)$, average annual evaporation $(r=0.666)$. At the same time the factors characterizing the solar radiation were only in 7 th and 8 th places for correlation coefficient values (Table 3). 
Table 5. Coefficients of pair correlation $(r)$ between separate climatic factors in Khabarovsk Krai

\begin{tabular}{|c|c|c|c|c|c|c|c|c|c|c|c|}
\hline & $\mathrm{X} 1$ & $\mathrm{X} 2$ & X3 & $\mathrm{X} 4$ & $\times 5$ & $x 6$ & $x 7$ & $\mathrm{X8}$ & X9 & $\mathrm{X} 10$ & $\mathrm{X} 11$ \\
\hline $\mathrm{X} 2$ & 0.680 & & & & & & & & & & \\
\hline $\mathrm{x} 3$ & -0.376 & -0.059 & & & & & & & & & \\
\hline $\mathrm{X} 4$ & -0.119 & -0.658 & -0.121 & & & & & & & & \\
\hline $\mathrm{X} 5$ & -0.416 & -0.551 & 0.321 & 0.727 & & & & & & & \\
\hline $\mathrm{x} 6$ & -0.737 & -0.742 & 0.209 & 0.662 & 0.801 & & & & & & \\
\hline$x 7$ & -0.791 & -0.530 & 0.524 & 0.382 & 0.727 & 0.912 & & & & & \\
\hline $\mathrm{x} 8$ & -0.445 & -0.639 & -0.108 & 0.803 & 0.794 & 0.803 & 0.584 & & & & \\
\hline X9 & -0.569 & -0.750 & 0.046 & 0.807 & 0.863 & 0.880 & 0.698 & 0.957 & & & \\
\hline $\mathrm{X} 10$ & -0.459 & -0.575 & 0.054 & 0.776 & 0.894 & 0.832 & 0.681 & 0.970 & 0.967 & & \\
\hline $\mathrm{X} 11$ & -0.585 & -0.851 & 0.031 & 0.844 & 0.829 & 0.924 & 0.714 & 0.908 & 0.959 & 0.892 & \\
\hline $\mathrm{X} 12$ & -0.759 & -0.806 & 0.329 & 0.673 & 0.835 & 0.981 & 0.907 & 0.771 & 0.877 & 0.811 & 0.928 \\
\hline
\end{tabular}

$\mathrm{X} 1-\mathrm{X} 12$ is climatic factors (see Material and Methods section).

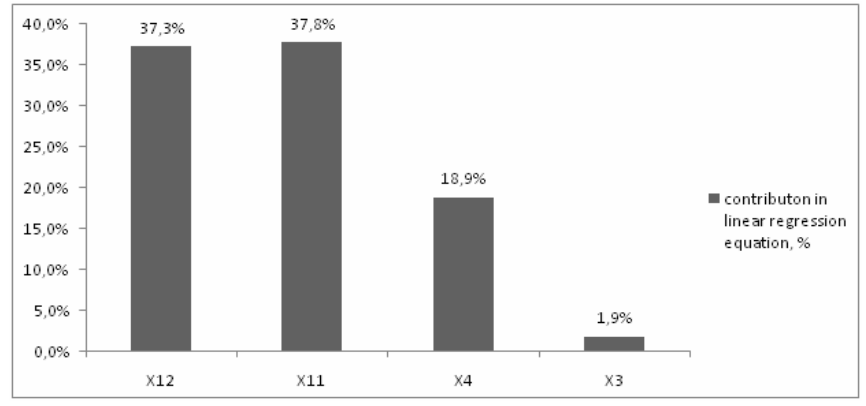

Figure 3. Contribution of climatic factors in the multiple linear regression equation for skin melanoma

The regression analysis performed allowed us to get the multiple linear regression equation as follows:

$$
Y=0.554 \times 12+0.088 \times 3+0.468 \times 4-0.053 \times 11 \text {, }
$$

where $Y$ - prevalence of skin melanoma in Khabarovsk Krai,

$\mathrm{X} 12$ - average monthly air humidity in July,

X3 - repetitiveness of murky sky in July,

$\mathrm{X} 4$ - average monthly air temperature in July,

$\mathrm{X} 11$ - average annual evaporation.

Approximation coefficient $R^{2}$ was $0.959,(p=0.018)$. At the same time the highest contribution to $Y$ value was made by components $\mathrm{X} 11$ (average annual evaporation) $-37.8 \%$ and $\mathrm{X} 12$ (average monthly air humidity in July) - 37.3\%, with the latter having negative value in the resulting equation. The contribution of components $\mathrm{X} 4$ (average monthly air temperature in July) and X3 (repetitiveness of murky sky in July) were $18.9 \%$ and $1.9 \%$ respectively (Figure 3).

Coefficients of pair correlation of all the mentioned factors with skin melanoma prevalence were high (Table 4). However the strongest degree of direct connection was noted with the levels of average monthly humidity in July ( $r=0.809$ ).

Correlation regression analysis showed that the high prevalence of skin melanoma in the Krai is associated with the effect of the set of climatic factors on population. Among them the most significant are the factors characterizing the specifics of the climate in July, first of all average monthly humidity levels. The parameters of average monthly humidity in July are closely related to the majority of climatic factors except for X3 (repetitiveness of murky sky in July). The most strong connection of average annual evaporation value is observed with the levels of annual total solar radiation and absorbed short-wave radiation ( $r=0.959$ and $r=0.892$ respectively), minimal air temperature in January ( $r=0.924)$, annual radiation balance $(r=0.908)$. The strongest direct connection for average monthly air temperature in July is noted with the levels of average annual evaporation $(r=0.844)$, annual total solar radiation $(\mathrm{r}=0.807)$ and annual radiation balance $(\mathrm{r}=0.803)$ (Table 5$)$.

\section{Discussion}

The study of prevalence of malignant skin neoplasms in Khabarovsk Krai population using climatic geographic information system detected the territorial differences in the disease prevalence levels related to the specific effects of environmental factors in population.

The relative risk of skin cancer and skin melanoma was not homogeneous in the Krai (increase in "southern clusters" relative to "northern" ones) which is related to non-homogeneous exposure to climatic factors and to the different role of particular factors in development of particular pathology.

The effect of different climatic factors on the risk of manifestation of skin cancer and skin melanoma is not similar. The factors increasing the risk of skin cancer include annual absorbed short-wave radiation and annual radiation balance, while the parameters of air humidity and temperature fluctuation display much less of effect on population. The relative risk of skin melanoma manifestation is the most connected to the factors characterizing the specifics of climatic regimen in July, first of all to the levels of average monthly humidity. High values of the abovementioned climatic parameters are noted in the clusters located in the southern territories with relatively mild January climate. Those territories are the most affected by tropical cyclones coming during the year, especially in July, from South China Sea region, which significantly decrease the total ozone content in atmosphere [10].

Undoubtedly the abovementioned factors are not carcinogenic on their own. But they can be seen as the markers of the territories most affected by such unfavorable climatic factors as high levels of solar insolation and climatic stress (combination of low air temperatures in winter and hot and wet summer).

The application of climatic geographical information system can greatly facilitate the regional programs of prevention and early diagnostics of both malignant neoplasms in general and skin cancer and skin melanoma in particular. Since each geographical information system is created for particular territory, the patterns given in this article cannot be considered universal. On the other hand the application of this method allows us to show with certain reliability the effect of environmental factors on disease prevalence in population. 


\section{Conclusion}

1. Effect of different climatic factors on the risk of skin cancer and skin melanoma differs.

2. High risk of skin cancer is mostly related to the effect of annual total solar radiation and annual absorbed short-wave radiation on population.

3. High risk of skin melanoma is associated with a set of factors characterizing the particularities of climatic regime of the territory in July: average monthly humidity and average monthly air temperature as well as repetitiveness of murky sky.

Conflict of interest: none declared.

\section{References}

1. Merabishvily VM, Starinsky VV. Malignant neoplasms in the world and in the certain Russian territories). In: Materials of All Russian Scientific Practical Conference Issues of Quality Management of Oncologic Aid to the population of the Russian Federation. Kazan, Russia, 2007: 101105. [Text in Russian]

2. Kosykh NE, Lopatin AS, Novikova OY, Savin SZ. Geological information systems in medical ecology tasks. Dalnauka Publ., Vladivostok, Russia, 2008. [Book in Russian]

3. Cancer Incidence in Five Continents, Vol. VIII. D. Parkin, S. Whelan, J. Ferlay, et al. ads. IARC Sci publ., Lyon, France, 2002.

4. Preston DS, Stern RS. Nonmelanoma cancers of the skin. N Engl J Med 1992; 327(23): 1649-1662. (doi: 10.1056/NEJM199212033272307) (PMID: 1435901)

5. Agar NS, Halliday GM, Barnetson RS, et al. The Basal layer in squamous tumors harbors more UVA then UVB fingerprint mutations: a role for UVA in human skin cancerogenesis. Proc Nat Acad Sci USA 2004; 101(14): 4954-4959.

6. Almahroos $\mathrm{M}$, Kurban $\mathrm{AX}$. Ultraviolet carcinogenesis in nonmelanoma skin cancer. Part 1: incidence rates in relation to geographic locations and in migrant populations. Skinmed 2004; 3(1): 29-36. (PMID: 14724410)

7. Bränström R, Kristjansson S, Dal H, Rodvall $Y$. Sun exposure and sunburn among Swedish toddlers. Eur J Cancer 2006; 42(10): 14411447. (PMID: 16737807) (doi: 10.1016/j.ejca.2006.02.008)

8. Leiter U, Garbe C. Epidemiology of melanoma and nonmelanoma skin cancer-the role of sunlight. Adv Exp Med Biol 2008; 624: 89-103. (PMID: 18348450) (doi: 10.1007/978-0-387-77574-6_8)

9. Molochkov VA, Khlebnikova AN. Skin cancer: Diagnostics, Prevention, Treatment. Together Against Cancer 2005; 2: 5-10. [Article in Russian]

10. Nerushev AF. Effect of intense atmospheric turbulence on the ozone layer of Earth. Hydrometeoizdat Publ., Saint-Petersburg, 2003. [Book in Russian]

\section{Authors:}

A.Y. Marocho - MD, D.Sc., Assistant professor, Department of oncology and radiology, Far East State Medical University, Khabarovsk, Russia;

Alex S. Vavrinchuk - MD, Assistant, Department of oncology and radiology, Far East State Medical University, Khabarovsk, Russia;

N.E. Kosyh - MD, D.Sc., Professor, Head of Department of oncology and radiology, Far East State Medical University, Khabarovsk, Russia;

E.V. Pryanishnikov - MD, Surgeon, Far East Clinical Centre of Oncology, Khabarovsk, Russia. 